\title{
REPRESENTATION OF FINANCIAL INSOLVENCY IN ENGLISH METAPHORS
}

\section{Ivanchenko M. Yu.}

\section{INTRODUCTION}

Any language is a universal system of signs, potentially capable of reflecting everything that constitutes the real world, describing any objects and phenomena of surrounding reality. However, different languages share the same subjects and phenomena in different ways. Language reflects reality, creates its own picture of the world, specific and unique to each culture.

Material values have significantly changed in the 21st century. Rapid economic development is interspersed with sudden financial crises. Material values play a significant role in determining people's social success. In modern society, the concepts of money, wealth, profit, reward, and well-being - all become inseparable. Researcher I. Golubovskaya, who has studied in details the concept of wealth and poverty in the world national pictures, notes that in British society money is emerging as a power that governs the whole world. ${ }^{1}$ This testifies to the national characteristics of this ethnic community, which were shaped by historical and social factors.

Naturally, under such conditions, the concept of financial insolvency comes to the fore, which determines the relevance of this scientific research.

The purpose of the study is to analyze the metaphorical actualization of financial insolvency in modern English and ways of its reproduction in Ukrainian translation.

Achieving this goal involves the following tasks: to identify thematic subgroups of financial insolvency metaphors; to analyze the mechanisms of phenomenon actualization; identify reference sources of its formation of the latter; identify the basic techniques of English financial insolvency metaphors reproduction in the Ukrainian language.

The object of the study is English metaphors of financial insolvency. The subject is this extracurricular phenomenon ways of actualization, and the ways of translation into Ukrainian.

\footnotetext{
${ }^{1}$ Голубовська І.О. Етнічні особливості мовних картин світу. К.: Логос, 2004. Ст. 250.
} 


\section{Principles of Financial Insolvency \\ Metaphoric Actualization in English}

Problems of language and thinking interconnection, language and culture, the impact of social processes on language phenomena are fundamental in modern linguistics. Today we can talk about the peculiar dominance of "three C" in linguistics - cognition, communication, culture. The study of language through the prism of psycho-mental and socio-cultural processes is the basis of many modern sciences (socio linguistics, psycho linguistics, cognitive linguistics, linguo-culturology).

Recent studies show that one of the nuclear concepts in the national world today is such valuable concepts as WEALTH, POVERTY, MONEY, which is also manifested at the verbal level. The mentioned concepts were analysed in a comparative aspect on the material of English and Slavic linguistic world picture by O. Bulyhina ${ }^{2}$, O. Holubyeva ${ }^{3}$, I. Mayorenko ${ }^{4}$, T. Milokhina ${ }^{5}$, V. Kopytsya ${ }^{6}$, T. Pymonova ${ }^{7}$, O. Struk $^{8}$, I. Chernyshenko ${ }^{9}$.

On the first stage of our study, we tried to outline the limits of extra language reality that expresses financial insolvency. Thus, according to the technical encyclopedia, the phenomenon of financial insolvency is present in the economy of any country with a market orientated relations. The latter take place as a result of economic imbalance when spends exceed incomes. It is also stated that bankruptcy is always financial insolvency, whereas financial insolvency does not always mean bankruptcy ${ }^{10}$. Financial insolvency is usually accompanied by the suspension of debt payments due to lack of funds; financial collapse, ruin. An important condition for a successful course of economic

${ }^{2}$ Булыгина Е. Ю. Лексическое воплощение концепта «деньги» в современной публицистике. Отражение русской языковой картины мира в лексике и грамматике. Новосибирск, 1999. Ст. 5-13.

${ }^{3}$ Голубева Е. В. Изучение концепта «деньги» методом семантического дифференциала. Языковая личность. Речевые жанры. М. : Прогресс, 2008. Ст. 44-47.

${ }^{4}$ URL: http://www.phillog.msu.ru/ rusist/bs/jsk_21.pdf.

${ }^{5}$ Милёхина Т. А. Российские предприниматели и их речь (образ, концепты, типы речевых структур). автореф. дис. ... канд. филол. наук. Саратов, 2006. 26 с.

${ }^{6}$ Копиця В. Є. Концепт “гроші” в англійській та українській лінгвокультурах.

${ }^{7}$ Пимонова T. Г. Вербалізація субконцепту POVERTY в структурі англомовного концепту WEALTH-POVERTY. URL: http://www.nbuv.gov.ua.

${ }^{8}$ Струк О. В. Асоціативне поле концепту ГРОШІ. Науковий вісник Волинського національного університету імені Лесі Украӥнки. 2009. № 16 : Філологічні науки. Мовознавство. Ст. 98-101.

${ }^{9}$ Чернишенко I. А. Ціннісні концепти «БАГАТСТВО» та «БІДНІСТЬ» фразеологічних картинах світу англійської та української мов. Мова $і$ культура. (Науковий журнал). К.: Видавничий Дім Дмитра Бурого, 2008. Вип. 10. Т. V (105). 328 с.

10 Большой энциклопедический словарь. СПб: Форинт, М.: Большая Российская энциклопедия, 2000. Ст. 34. 
processes is the solvency of legal entities or organizations participants. No wonder why insolvency has become the crucial force behind the formation of many phraseologisms, expressions, proverb and sayings, idioms and metaphors that are the subject of our scientific exploration. The subject of scientific research is the mentioned phenomenon of extra-linguistic reality representation peculiarities.

Within the framework of this scientific article we figured out the thematic subgroups of financial insolvency metaphors.

Therefore, as a result of the analysis, we have identified the following thematic groups of metaphors that express financial insolvency in English.

The largest group of insolvency metaphors is formed by expressions that indicate a deterioration in financial standing. External indicator of material wealth is the appearance of a person, his clothes, living conditions.

This coat has seen better days. I need a new one (2, 73).

Tom's house needs paint. It looks down at heel $(3,98)$.

Money limit, inability to pay for their needs is updated with the verb short. The process of conceptualization took place due to the presence of seme "limited, insufficient" in its predicate semantic structure:

Browns had a thin time of it when the children were small and $\mathrm{Mr}$. Brown was poorly paid $(5,71)$.

Usually at the end of the month, I'm short of money $(4,102)$.

Fundamental economic category, which means the amount of money for which the seller agrees to sell, and the buyer is ready to buy a unit of goods is the price ${ }^{11}$. The imbalance in market relations between the seller and the buyer is the cause of financial insolvency. A certqain group is formed by English metaphors, which signify overpricing. Example:

Do I look as though I can afford a house that costs the earth? $(1,25)$.

For greater expressiveness, overwhelming prices are actualized as incompatible with life. Thus, indirectly indicates the inability of buyers to buy the product at such a price. The context literally indicates that people are more likely to starve to death than make a purchase:

It is no use buying raw commodities at cut-throat prices if the result is to impoverish prospective customers (5, 129);

It cost an arm and a leg, so I didn't buy it $(2,144)$.

To the same group we have attributed the opposite meaning - to buy cheap, "almost for free". In this case, these expressions have a negative connotation - to sell, to work without profit:

Flats to rent here are no longer two a penny $(3,197)$.

${ }^{11}$ Великий тлумачний словник сучасної української мови (з дод. і допов.). Уклад. і голов. ред. В. Т. Бусел. К.; Ірпінь: ВТФ «Перун», 2005. Ст. 523. 
In Italy, the peaches are dirt cheap $(4,31)$.

As we mentioned above, bankruptcy is always a financial failure. More precisely, it is a process in which an individual or an organization is unable to pay its debts ${ }^{12}$. This group includes the following examples:

Our profits have hit rock bottom. This is our worst year ever (2, 79).

Look, John, I'm in a tight spot. Can you lend me E20? _ I'm in a spot too. I need $£ 300(4,97)$.

An interesting example is: No wonder Jack's in Queer Street. He spends more than he earns $(4,89)$. This term is used to refer to persons with particular difficulties, mainly financial. In English, this is associated with Queer Street, which once housed the Bankruptcy Courts of London.

On of metaphors group are expressions that indicate a failed purchase, sale of a product, a business transaction. (1, 318).

Buying a car without test driving it is like buying a pig in a poke

I made some bad investments last year, and it looks as though I may go broke this year $(5,59)$.

The show was so bad we felt we hadn't got our money's worth $(3,53)$.

Getting into a difficult financial situation, people often seek help, borrow, that is, borrow anything:

Go to the bank and ask for the loan again. This time try not to come away empty-handed $(2,14)$.

In most cases, insolvency is caused by the emergence of debt, which in the English language is compared to the fall, the run, which call for rapid movement across space over considerable distances. Thus, the suddenness and speed of this problem and its global nature are emphasized:

Big four soccer clubs continue to run into debts $(3,172)$.

The consequence of the deterioration of the financial situation is saving, that is, thrift, savings in spending anything ${ }^{13}$. This group includes the expressions:

For the last two years, we have had to get by on a shoe-string $(3,51)$. $(5,146)$.

Bob has to pinch and scrape all the time because of his low wages

The only way out of a difficult financial situation is to save, that is, thrift, savings in the use of profits.

... our coals and candles were painfully economized - the pair of candles reduced to one, and that most sparingly used $(2,6)$.

${ }^{12}$ Великий тлумачний словник сучасної української мови (з дод. і допов.). Уклад. і голов. ред. В. Т. Бусел. К.; Ірпінь: ВТФ «Перун», 2005. Ст. 97.

${ }^{13}$ Ibid. Cт. 254. 
Savings are conceptualized with the verb to cut, which nominates the process of splitting an object using sharp objects:

We cut our expenses to the bone and are still losing money $(1,69)$.

In this example, the use of this predicate provides expressive quotation, since the use of this method of changing the object structure allows you to define clearly the boundaries and the result of (cutting). The choice of the predicate is made due to the specificity of the extralinguistic phenomenon.

Unreasonable use, waste of money, property is called waste ${ }^{14}$. This concept has combined into a separate group English metaphoric expressions denoting financial failure. In English, this extra-linguistic phenomenon is expressed by the verbs to splash, to pour, to throw. Thus, profligacy by analogy is compared with spillage, scattering. The transfer from the sphere of the concrete to the sphere of the abstract took place due to the presence of seme "careless, false" in these predicates semantic structure.

The Browns are always throwing good money after bad, They bought a plot of land which turned out to be swamp, and then had to pay to have a filled in $(5,192)$.

Jack splashed out on a new car that he couldn't afford (4, 181).

Don't buy any more of that low-quality material. That's just pouring money down the drain $(3,151)$.

Often the deterioration of the financial situation causes the immoral and unlawful actions of the subject, such as fraud, theft, etc. We have included the following examples in this group:

Mary is also enjoying her ill-gotten gains. She deceived an old lady into leaving money to her in her will $(2,83)$.

Jane was sent to jail for cooking the books of her mother's shop $(1,25)$.

\section{The Sources of Financial Insolvency Metaphors Formation in English}

The next objective of our study is to identify the sources of financial insolvency metaphors formation in English.

Recent years' research shows that "the transfer of a conceptual domain (domain) structure to a source domain ("a mapping of the structure of a source model onto a target model") ${ }^{15}$ occurs as a result of the phenomena passing and events of extra-linguistic reality through the prism of the individual's

${ }^{14}$ Великий тлумачний словник сучасної української мови (з дод. і допов.). Уклад. і голов. ред. В. Т. Бусел. К.; Ірпінь: ВТФ «Перун», 2005. Ст. 455.

${ }^{15}$ Lakoff, G., Johnson, M. Metaphors We Live By. Chicago, IL: University of Chicago Press, 2003. P. 7. 
worldview, in particular as a particular linguistic collective representative, and naturally expresses an opinion in general.

Historical and cross-cultural studies have proven that metaphor has historically and culturally specific sources of education ${ }^{16}$, that is, sources that are not universal but linked to particularities of historical and cultural development.

As a result of the analysis of sources of metaphors formation in English, indicating financial insolvency, we have figured out that the latter cover a wide range of extralinguistic phenomena. The theoretical basis for of these groups pointing out was the research of V. Belyakov ${ }^{17}$ and Y. Zinken ${ }^{18}$. So, we tried to divide the examples we selected according to the source sphere into 2 groups: "Man and nature", "Means and results of human activity". The source areas we have identified include the following reference subcategories: I - Man and nature: 1) anthropomorphisms (somatisms); 2) nature: a) fauna, b) space, c) shape; II - Means and results of human activity: 1) buildings, 2) artifacts.

The part of the environment always tried to compare it with itself, with their images, thoughts and attributed to the phenomena of the world that surrounded it, those properties that it had, correspondingly identifying with nature and pointing to their emotional and physical states. This is confirmed by the analysis of the metaphors we have inventoried, which showed that the source-field before the formation of most of them is the reference sub-category "nature".

So, unsuccessful purchase is compared with animals pup, pig, etc.:

The salesman sold Jane a pup when he persuaded her to buy the secondhand washing-machine. Water pours out of it $(3,172)$.

A certain amount of insolvency metaphors are formed on the basis of associative relationships with nature: hill, rock, etc. What is the deterioration of financial situation by analogy with the rapid movement down, the foot of the mountain, the hill:

This industry is going downhill. We lose money every year $(1,59)$.

On the other hand, the inflated price compares to the heavens or the globe:

Prices go sky-high whenever there is inflation $(4,62)$.

${ }^{16}$ Geeraerts D. Conceptual Structure and Conceptual Variation. Shanghai: Shanghai Foreign Language Education Press, 2017. 345 p.

${ }^{17}$ Zinken, J. Metaphors, stereotypes, and the linguistic picture of the world: Impulses from the Ethnolinguistic School of Lublin. URL: www.metaphorik.de/10/beliakov.pdf.

${ }^{18}$ Beliakov, V. La réalité russe à travers la métaphorisation des discours médiatiques. URL: www.metaphorik.de/07/zinken.pdf. 
Spatial sources were also productive. For example, financial insolvency appears as a decrease in space or a loss of form, for example to fall into debts, to fall behind, to leave flat, etc. :

Many people hurry to say that they will never fall into debts $(5,74)$.

Teenagers were more likely to fall behind with the rent $(4,117)$.

The robber took all my money and left me flat $(1,202)$.

In some cases, financial failure can be expressed through human physiology, so-called somatism. In particular, the back symbolizes insecurity, hence the financial problems are actualized due to the physiological limitations of moving in space:

How can I bargain when I've got my back to the wall? $(2,73)$.

Often, expressions containing somatism are based on an associative relationship with linguistic phenomena that express irrelevant effects:

Why should you pay through the nose? $(4,144)$.

I think that the new shop assistant has her hand in the till. There is cash missing every morning $(3,73)$.

The source of the studied metaphors formation are also artifacts. Artifact, from the Latin artefactum, "artificially made" - a phenomenon, process, object, property of an object or process, the occurrence of which under observed conditions is impossible or unlikely under natural conditions; it is the product of human activity, the object of material culture. The appearance of an artifact is a sign of deliberate interference with the process or the presence of some unaccounted factors ${ }^{19}$. This reference subcategory of the metaphors under study appeals to the items of clothing that are actualized as indicators of material well-being, and, accordingly, the absence or deliberate reduction of the latter - financial insolvency -

Things are beginning to cost more and more. It looks as though we'll all have to tighten our belts $(4,193)$.

We would like a bigger house, but we must cut our coat according to our cloth $(2,27)$.

\section{Peculiarities of Financial Insolvency Metaphors Reproduction in Ukrainian Translation}

Translation of any language means of expression is a process of intercultural communication, dialogue of cultures. The success of the aforementioned means depends on the accuracy of perception and the ability to find adequate matches that are acceptable in the target audience by the translator. The difficulties involved in translating metaphors are due to the fact

${ }^{19}$ Prinz J. Furnishing the Mind: Concepts and Their Perceptual Basis. Cambridge, Mass: MIT Press, 2004. 368 p. 
that the latter is the unit of culture of a particular language. The causes of such problems are the following factors: lack of adequate equivalent in the language of translation, difference in cultures norms and value systems, contrast in the languages realities. However, in order to ensure a successful dialogue and a maximum understanding of another country culture, it is important to translate metaphors.

The translation process lies in the continuous search for a balance between the source language and the translation language ${ }^{20}$, since the main task of the translator is to reproduce the picture of the world as accurately as possible ${ }^{21}$. To understand the peculiarities of native speaker's perception, and thus to reconstruct their linguistic world picture, it is precisely the analysis of metaphors that, in turn, is a prerequisite for the adequate translation implementation ${ }^{22}$.

Peter Newmark identifies two main functions of metaphor: connotative and aesthetic. The connotative function refers to the ability of a metaphor to describe certain objects, concepts, to characterize any object. The aesthetic function is determined by the ability of the metaphor to exert an aesthetic effect on the recipient, to arouse interest and to engage in the further perception of the message ${ }^{23}$.

Accordingly, the loss of the metaphor in translation may cause the meaning to be incompletely conveyed, and the translator must find any means of translation to preserve meaning ${ }^{24}$.

In translation theory, there is a "law of metaphor preservation", according to which, when possible, the metaphorical image must be preserved in translation. Failure to comply with this law causes the change of the phrase meaning and its aesthetic and pragmatic effect is being diminished ${ }^{25}$.

The degree of the translation authenticity depends not only on how the translation is performed, but also on how closely the cultural and linguistic traditions of the original language are close together. Metaphorical semantics are made up of several interrelated elements: the initial meaning of the word, the image created by the mapping, and the new conceptual content, the new

${ }^{20}$ Кравцова Ю. В. Особенности индивидуальной метафорической картины мира. Науковий часопис Начіонального педагогічного університету імені М. П. Драгоманова. Серія № 9.Сучасні тенденції розвитку мов. Випуск 6: зб. наук. праць. К. : 2011. Ст. 23-24.

${ }^{21}$ Некряч Т. Є. Через терни до зірок : труднощі перекладу художніх творів : [навч. посіб. для студ. переклад. ф-тів ВНЗ]. Вінниця : Нова книга, 2008. Ст. 11.

${ }^{22}$ Опарина, Е. О. Исследования метафоры в последней трети ХХ в. Лингвистические исследования в конце ХХ в. : сб. обзоров. М., 2000. С. 70.

${ }^{23}$ Щикалов С.В. Способы перевода метафор в концепции Питера Ньюмарка. URL: http://www.thinkaloud.ru/science/shik-newmark.pdf

${ }^{24}$ Комиссаров В.Н. Современное переводоведение. Курс лекций. М.: ЭТС, 1999. Ст. 115.

${ }^{25}$ Гак В.Г. Метафора: универсальное и специфическое. Метафора в языке и тексте. М., 1988. Ст. 74. 
nomination resulting from the metaphor understanding ${ }^{26}$. The competence of the translator attests to the metaphor understanding, that is, to comprehend the associative content of the lexical or phraseological unit, to identify the reproduction of the metaphorical expression by the means of the target language, avoiding materially the false associations and erroneous connections of the meaning. The main difficulty for the translator is to convey the semantics of the metaphor adequately. The job of the translator is to compare the lexical meaning of the words of the original language and the translation language. Quite often, linguistic images of the original language metaphorical word combinations can be conveyed by metaphorical images that are equal in nominative function and have an equivalent semantic basis. However, to overcome the difficulty of transmitting a metaphor in one's own language, the person performing the translation may also resort to verbal replacement of the metaphor's elements, replacement or alteration of the image, removal of the figurative value and translation with the full equivalent ${ }^{27}$.

Today, the methods of metaphor translation taking to account the presence or absence of forced structural or semantic transformations in translation are distinguished by linguists M. A. Kunilovskaya and N. V. Koro$\operatorname{vodina}^{28}$ : a complete translation that preserves the semantics and structure of the metaphor in the text, and the lexical meaning of phrases causes the same associations in the representatives of both languages; replacement at the level of lexical design; replacement at the level of morphological design; syntax-level replacement; adding or avoiding lexical units that make up the image.

In this study, we looked at metaphors that actualize financial insolvency that we think are most interesting and illustrative in terms of linguistic analysis. In most cases, metaphors and their translation are significantly different in structure of expression and in an actualized way. This is obviously due to the fact that the linguistic picture of the world of each individual as a representative of a particular group and of the whole nation as a whole is a product of the surrounding reality perception through the prism of a certain norms and values system ${ }^{29}$.

${ }^{26}$ Романюга Н. В. Відтворення метафоричної образності при перекладі української прози англійською мовою (на матеріалі оповідання В. Винниченка «Голод»). ВІСНИК Житомирськ. держ. ун-ту імені Івана Франка (38). Житомир, 2008. Ст. 219.

${ }^{27}$ Некряч Т. Є. Через терни до зірок : труднощі перекладу художніх творів : [навч. посіб. для студ. переклад. ф-тів ВНЗ]. Вінниця : Нова книга, 2008. Ст. 56.

${ }^{28}$ Куниловская М. А., Короводина, Н. В. Авторская метафора как объект перевода. Научный журнал № 4 (23) под ред. Селютина А. А. Челябинск, 2010. Ст. 78.

${ }_{29}$ Дебердеева Е. Е., Шатун О. А., Поленова Г. Т. Актуальные проблемы когнитивной лингвистики и концептологии (на примере сопоставительного изучения языков). Таганрог : Изд. Центр Таганрог. гос. пед. ин-та, 2009. Ст. 101. 
Knowing the surrounding reality, a person, as a subject of speech activity, constantly "project" it into language by comparing and identifying the abstract with the concrete. This is precisely the mechanism of the metaphor, which is inherently related to the mechanism of analogy. Scientists have come to the conclusion that metaphorization is a natural ability of man, a metaphor a form of thinking, and a metaphorical model an instrument of cognition and explanation of reality.

However, among the metaphors we analyze, we find cases where direct translation is possible due to the coincidence of imaginative connotations that provide speakers of both languages with a certain vocabulary. In this case, we observe the reception of so-called metaphor calculation. The cause of this phenomenon is the same structuring of knowledge in different languages, especially those fragments that are common in the world conceptual pictures ${ }^{30}$.

For example, the metaphor "being in a difficult financial situation":

I'm sure now he has his back to the wall because he has lost his job $(10,56)$.

Я впевнений зараз він припертий до стіни через те, що втратив роботу.

This example shows that speakers of both languages, English and Ukrainian, have financial problems associated with hopelessness, insecurity, and limited space travel.

Another illustration of the commonality of linguistic means, the somatisms used to actualize the absence of material existence means:

Go to the bank and ask for the loan again. This time try not to come away empty-handed $(2,14)$. Іди до банку та попроси знову позику. Цього разу спробуй не повернутись з порожніми руками.

A similar negative connotation common to both languages can be seen in the example:

This coat has seen better days. I need a new one $(6,45)$. Це пальто бачило кращі часи. Мені потрібне нове.

Another example is the translation of the metaphor semantics and structure, and the lexical meaning of words causes the same associations in the representatives of both languages. These are metaphors that illustrate "savings" as a result of financial problems, when the rational use of funds by analogy is compared with a slim figure:

Things are beginning to cost more and more. It looks as though we'll all have to tighten our belts $(7,193)$.

Товари починають коштувати все дорожче. Виглядає так, щзо ми всі будемо змушені затягнути пояси.

\footnotetext{
${ }^{30}$ Чередниченко О. Про мову і переклад. К. : Либідь, 2007. Ст. 165.
} 
However, in most cases, when translating metaphors, the translator has to resort to varying degrees of variation and change in the source text.

For example,

Big four soccer clubs continue to run into debts $(10,172)$. Чотири великі футбольні клуби продовжують влазити у борги. - ілюструє метод лексичної заміни.

Due to the difference in the perception of the surrounding reality in English and Ukrainian speakers, debts as a result of insolvency are updated differently, but in related categories, namely, moving over space on a considerable distances. This illustrates the problem global nature.

За тим самим принципом перекладається метафора:

Buying a car without test driving it is like buying a pig in a poke (18).

Купувати машину без тест драйву це те саме, що купувати кота у мішку.

The replacement is due to the fact that the lexical semantics reflects the "consciousness" of the ethnos in which the memory and history of the people, its experience of cognitive activity, worldview and psychology are enshrined.

The company went broke cause no one did buy its production (19).

Компанія прогоріла, збанкрутувала тому, що ніхто не купував іï продукиію.

The aforementioned translation technique is used in this case in view of the impossibility of literal translation of the structure went broke as incomprehensible to the Ukrainian-speaking recipient, so the synonym "burned out" is introduced in the context.

Some other examples illustrating the choice of lexical material due to the difference between "figurative analog-associative ideas about the world existing in the national consciousness of a given ethnic group and explicating in language" 31 .

We would like a bigger house, but we must cut our coat according to our cloth $(8,27)$. Ми хотіли б більший будинок, однак ми мусимо по своєму ліжку простягати ніжку.

I can't buy that car - it costs an arm and a leg $(16,245)$. Я не можу купити цюю машину - вона коштує як космічний корабель.

Sometimes the translator applies so-called demetaphorization mean of translation transformation. The essence of this technique is to refuse to convey the figurative meaning of a metaphorical expression and to translate only its literal meaning. Such a technique is used by the translator when it is impossible to find an adequate equivalent.

${ }^{31}$ Кравцова Ю. В. Особенности индивидуальной метафорической картины мира. Науковий часопис Національного педагогічного університету імені М. П. Драгоманова. Серія № 9. Сучасні тенденції розвитку мов. Випуск 6: зб. наук. праць. К. : 2011. Ст. 125. 
Such translating approach take place in the next example: No wonder Jack's in Queer Street. Hе spends more than he earns $(16,32)$. Не дивно, що Джек переживає великі фінансові труднощі. Він витрачає більще ніж заробляє.

Queer street is translated by description since this extralinguistic phenomenon is specific to the English-speaking community. At one time, the Bankruptcy Courts were located on Karei Street.

Similarly, in the Ukrainian language, it is impossible to find an adequate equivalent of a metaphor since the latter contains the English-only quotation leave someone flat:

Paying all my bills left me flat $(9,554)$. Коли я оплатив усі рахунки, у мене не залишилося ані иенту.

The same principle is applied in the next metaphors translation:

They didn't pinch pennies on the new opera-house (5, 39). На будівництво оперного театру не шкодували грошей.

Big grey limousine. - Expensive? - Looked as if it had cost the earth $(3,25)$.

Це був великий сірий лімузин. - Дорогий? - Судячи з вигляду, надзвичайно.

Don't buy any more of that low-quality material. That's just pouring money down the drain $(10,151)$. Не купуй більше той матеріал низької якості. Це просто марна трата грошей.

Jane was sent to jail for cooking the books of her mother's shop $(1,25)$.

Джейн відправили до в'язниці за фальсифікацію бухгалтерських книг з магазину ї мами. The selection of a translation equivalent is used in cases where the original idea cannot be transmitted in the same way. In such cases another, more or less equivalent variant in the language of translation is selected.

For example: In Italy, the peaches are dirt cheap (2, 31). B Imaлii персики дешеві як дірки від бублика.

Usually at the end of the month, I'm short of money $(5,102)$. Зазвичай y кіниі місяия у мене у кишені гуде.

I've been living on a shoestring since my father stopped sending me, топеу (6, 315). 3 тих пір, як батько перестав надсилати мені гроші, мені довелося рахувати кожну копійку.

Browns had a thin time of it when the children were small and Mr. Brown was poorly paid (5, 71). Брауни годували злидні коли діти були малі і Містеру Брауну мало платили. 


\section{CONCLUSIONS}

The fulfilled analysis shows that financial insolvency in English language metaphors is actualized with the help of verbs in the semantics of which there is a seme "fast moving in space" to go, to run; "negligent, false" to throw, to splash; to limit - to tight, to cut, to reduce; adjectives with the term "limited" - thin, little, short; "deprived (of form, content)" - flat, empty; adverbs pointing down, behind - down, behind. In English, the sources of financial insolvency metaphors formation are human, the world of nature, the world of human activity results. The the metaphors of the above types high performance took place due to the fact that the anthropomorphic sphere, subject (artifact), are the main models that form the basis for the interpretation of the phenomenon under study. On the other hand, such processing of linguistic material is important because "at the heart of the abstract name is the idea of its abstract essence, which has developed in a given culture and is transmitted by tradition ..."32.

The analysis of translation transformations clearly shows the difference in the perception of extralinguistic phenomena by different languages native speakers. Thus, in English, the rational use of money from the family budget is associated with the elements of clothing, whereas in the Ukrainian with furniture. The inflated prices in the linguistic consciousness of the English are by analogy compared with the extremities, and in Ukrainians - with the cost of an unattainably expensive item. Historical sources of metaphor that illustrate poverty in English are the physical characteristics of the object, in Ukrainian it is folklore, mythology. A bad purchase is also updated differently. In the semantics of lexical units, by which debt acquisition is expressed, there is a common sema "to move in space over long distances", but the figurative component is different.

The analysis showed that $80 \%$ of metaphors that actualize financial insolvency have undergone translation transformations. Reception of lexical replacement is applied in 15\% of metaphors; demetaphorization occurs in $28 \%$; the search for an equivalent was done in $37 \%$ of the inventory examples.

The prospect of the study, in our opinion, is to compare ways to reproduce metaphors of financial insolvency with the principles of translation of metaphors of related reference spheres.

\section{SUMMARY}

The financial insolvency in English idioms is actualized with the help of the verbs which have seme "to move rapidly in space", "to fail, to make a slip", "to limit" in their semantic structure; adjectives with the seme "limited",

\footnotetext{
${ }^{32}$ Чернейко Л. О. Лингво-философский анализ абстрактного имени. М., 1997. Ст. 35.
} 
"deficient, deprived", adverbs - down, behind. The specific historical and cultural sources of the financial insolvency metaphors formation are human, the world of nature, the world of human activity results.

The analysis of translation transformations clearly shows the difference in the perception of extra-language phenomena by different speakers. So, in English, the rational use of money from the family budget is associated with the elements of clothing, while in the Ukrainian with furniture. Excessive prices in the English linguistic consciousness, by analogy, are compared to the limbs, and in Ukrainian - with the cost of an inaccessible item.

The historical sources of the metaphors formation that illustrate poverty in the English language are the physical characteristics of the object, in Ukrainian - folklore, mythology. Unsuccessful purchase is also updated in different ways. In semantics of lexical units, by means of which the acquisition of debts is expressed, a common seme "to move in space over long distances" is available, but the image component differs.

\section{REFERENCES}

1. Большой энциклопедический словарь. СПб: Форинт, М.: Большая Российская энциклопедия, 2000. 684 с.

2. Булыгина Е. Ю. Лексическое воплощение концепта «деньги» в современной публицистике. Отражение русской языковой картины мира в лексике и грамматике. Новосибирск, 1999. С. 5-13.

3. Великий тлумачний словник сучасної української мови (з дод. і допов.). Уклад. і голов. ред. В. Т. Бусел. К.; Ірпінь: ВТФ «Перун», 2005. $728 \mathrm{c}$.

4. Гак В.Г. Метафора: универсальное и специфическое. Метафора в языке и тексте. М., 1988. 174c.

5. Голубева Е. В. Изучение концепта «деньги» методом семантического дифференциала. Языковая личность. Речевые жанры. М. : Прогресс, 2008. С. 44-47.

6. Голубовська I.О. Етнічні особливості мовних картин світу. К.: Логос, 2004. 282 c.

7. Дебердеева Е. Е., Шатун О. А., Поленова Г. Т. Актуальные проблемы когнитивной лингвистики и концептологии (на примере сопоставительного изучения языков). Таганрог : Изд. Центр Таганрог. гос. пед. ин-та, 2009. 240 с.

8. Комиссаров В.Н. Современное переводоведение. Курс лекций. М.: ЭТС, 1999. $192 \mathrm{c.}$

9. Копиця В. Є. Концепт «гроші» в англійській та українській лінгвокультурах. URL: http://www.nbuv.gov.ua/portal/Soc_Gum/Apif/ 2009_3/Kopicja.pdf 
10. Кравцова Ю. В. Особенности индивидуальной метафорической картины мира. Науковий часопис Нациіонального педагогічного університету імені М. П. Драгоманова. Серія № 9.Сучасні тенденції розвитку мов. Випуск 6: зб. наук. праць. К. : 2011. 246 с.

11. Куниловская М. А., Короводина, Н. В. Авторская метафора как объект перевода. Научный журнал № 4 (23) под ред. Селютина А. А. Челябинск, 2010. С. 73-82.

12. Майоренко И. А. Концепт «деньги» в языковой картине мира (на материале русской и английской фразеологии). URL: http://www.phillog.msu.ru/ rusist/bs/jsk_21.pdf.

13. Милёхина Т. А. Российские предприниматели и их речь (образ, концепты, типы речевых структур). автореф. дис. ... канд. филол. наук. Саратов, 2006. 26 с.

14.Некряч Т. Є. Через терни до зірок : труднощі перекладу художніх творів : [навч. посіб. для студ. переклад. ф-тів ВНЗ]. Вінниця : Нова книга, 2008. 195 с.

15. Опарина, Е. О. Исследования метафоры в последней трети $\mathrm{XX}$ в. Лингвистические исследования в конще $X X$ в. : сб. обзоров. М., 2000. C. $65-77$.

16. Пимонова Т. Г. Вербалізація субконцепту POVERTY в структурі англомовного концепту WEALTH-POVERTY. URL: http://www.nbuv.gov.ua.

17. Романюга Н. В. Відтворення метафоричної образності при перекладі української прози англійською мовою (на матеріалі оповідання В. Винниченка «Голод»). ВІСНИК Житомирськ. держ. ун-ту імені Івана Франка (38). Житомир, 2008. С. 217-220.

18. Струк О. В. Асоціативне поле концепту ГРОШІ. Науковий вісник Волинського національного університету імені Лесі Украӥнки. 2009. № 16 : Філологічні науки. Мовознавство. С. 98-101.

19. Чередниченко О. Про мову і переклад. К. : Либідь, 2007. 248 с.

20. Чернейко Л. О. Лингво-философский анализ абстрактного имени. М., 1997. 157 с.

21. Чернишенко I. А. Ціннісні концепти «БАГАТСТВО» та «БІДНІСТЬ» у фразеологічних картинах світу англійської та української мов. Мова і культура. (Науковий журнал). К.: Видавничий Дім Дмитра Бурого, 2008. Вип. 10. T. V (105). 328 с. С. 154-161. XVI Міжнародна наукова конференція "МОВА І КУЛЬТУРА" - Київ, 23-27 червня 2007 р.

22. Щикалов С.В. Способы перевода метафор в концепции Питера Ньюмарка. URL: http://www.thinkaloud.ru/science/shik-newmark.pdf.

23. Geeraerts D. Conceptual Structure and Conceptual Variation. Shanghai: Shanghai Foreign Language Education Press, 2017. 345 p. 
24. Lakoff, G., Johnson, M. Metaphors We Live By. Chicago. URL: University of Chicago Press, 2003. 193 p.

25. Prinz J. Furnishing the Mind: Concepts and Their Perceptual Basis. Cambridge, Mass: MIT Press, 2004. 368 p.

26. Zinken, J. Metaphors, stereotypes, and the linguistic picture of the world: Impulses from the Ethnolinguistic School of Lublin. URL: www.metaphorik.de/10/beliakov.pdf.

27. Beliakov, V. La réalité russe à travers la métaphorisation des discours médiatiques. URL: www.metaphorik.de/07/zinken.pdf.

\section{SOURCES}

1. Collins Cobuild Dictionary of Phrasal Verbs. $2^{\text {nd }}$ edition. London: Harper Collins Publishers, 2006. 512 p.

2. Dictionary of Word and Phrase Origins. (ed. by Nigel Rees). N.Y. 1994, 220 p.

3. Magnuson W. Canadian English Idioms. Sayings and Expressions. Prairie House Books Calgary, Alberta, Canada, 1993. 112 p.

4. The Oxford Dictionary of English Proverbs. (ed. by F.P. Wilson). Oxford University Press 1992. 860p.

5. The Penguin Dictionary of Proverbs. (ed. by Rosalind Fergusson). 1983. $331 \mathrm{p}$.

6. Oxford Dictionary of Phrasal Verbs. (ed. by A.P. Cowie \& R. Mackin). Oxford University Press 1994. 515 p.

7. Oxford Dictionary of Current Idiomatic English. V1. Phrasal Verbs. (ed. by A.P. Cowie, R. Mackin ). Oxford University Press 1991. 396 p.

8. Oxford Dictionary of Current Idiomatic English. V2. English Idioms. (ed. by A. P. Cowie \& R. Mackin) Oxford University Press 1991. 690 p.

9. Oxford Phrasal Verbs Dictionary for Learners of English. Oxford University Press 2001. 377 p.

10. Alcott L.M. An Old-Fashioned Girl. Retrieved from: www.freeebooks.net/An_Old-Fashioned_Girl.html.

11. Alcott L.M. Eight Cousins. Retrieved from: www.free-ebooks.net/ Eight_Cousins.html.

12. Arnim E. Christopher and Columbus. Retrieved from: www.free-ebooks.net/Christopher_and_Columbus.html.

13. Austen J. Sense and Sensibility. London : Wordsworth classics, 1992. 257 p.

14. Ellis A.C. \& Stalen J. Death Jag. Retrieved from: www.free-ebooks.net/Death_Jag.html.

15. Hillerman T. People of Darkness. Retrieved from: www.free-ebooks.net/People_of_Darkness.html. 
16. Joyce J. Dubliners. Retrieved from: www.free-ebooks.net/ Dubliners.html.

17. Joyce J. Ulysses. Retrieved from: www.free-ebooks.net/ Ulysses.html.

18. London J. White Fang. Retrieved from: www.free-ebooks.net/ White_Fang.html.

19. Maugham W.S. The Magician. Retrieved from: www.free-ebooks.net/ The_Magician.html .

20. Ryman E. Doctor Mooze. Retrieved from: www.free-ebooks.net/ Doctor Mooze.html .

21. Sharma R. Caterpillar to Butterfly. Retrieved from: www.free-ebooks.net/Caterpillar_to_Butterfly.html.

22. Woolf V. Mrs Dalloway. New York: Penguin Putnam Inc., 1996. $127 \mathrm{p}$.

\section{Information about the author:} Ivanchenko M. Yu.,

Candidate of Philological Science, Assosiate Professor at the Department of Foreign Languages and Translation,

Lviv State University of Life Safety 35, Kleparivsjka str., Lviv, 79000, Ukraine 